\title{
The effect of environmental conditions on diapause in the blister beetle, Mylabris phalerata (Coleoptera: Meloidae)
}

\author{
Fen ZHU ${ }^{1}$, FangSen XUE ${ }^{2}$ and Chaoliang LEI ${ }^{1 *}$ \\ ${ }^{1}$ Institute of Insect Resource, Huazhong Agricultural University, Wu Han 430070, People's Republic of China \\ ${ }^{2}$ Institute of Entomology, Jiangxi Agricultural Universty, Nanchang 330045, People's Republic of China
}

Key words. Meloidae, Mylabris phalerata, temperature, photoperiod, soil water content, larval diapause, diapause intensity, sensitive stage

\begin{abstract}
In the field, the blister beetle Mylabris phalerata Pallas (Coleoptera: Meloidae) undergoes larval diapause in the ground, which lasts for nearly six months. The effect of the soil environment on this diapause was examined. Final instar larvae kept at temperatures of $\geq 26^{\circ} \mathrm{C}$ do not enter diapause and continued to develop regardless of the soil water content and photoperiod. Below $25^{\circ} \mathrm{C}$ the final instar larvae entered diapause regardless of soil water content and photoperiod. The early stages, particularly L2, appeared to be more important for diapause induction than the later stages. However, the other instars were also sensitive. Temperature, rather then photoperiod was the main factor influencing pupal duration.
\end{abstract}

\section{INTRODUCTION}

Many animals have evolved to survive seasonally recurring adverse conditions by entering a diapausing stage. To this end, many insects respond to one or many environmental factors as cues for diapause. Photoperiod is the most common environmental factor inducing the onset of diapause in temperate-zone insects (Tauber et al., 1986; Danks, 1987; Saunders, 2002). In many insects temperature is another important factor controlling diapause, especially in insects living in warehouses and underground. Diapause in soil-inhabiting insects can be influenced by soil temperature, moisture and oxygen (Lee \& Denlinger, 1990). Diapause in soil-inhabiting insects is an important topic, which is poorly studied. The present study investigates the effects of soil environmental conditions, including temperature, photoperiod and water content, on diapause in Mylabris phalerata (Coleoptera: Meloidae).

M. phalerata is found usually on flowers of cowpea (Vigna unguiculata) and loofah (Luffa cylindrical). Cantharidin from Mylabris is used in medicine (Wang, 1989; Hundt et al., 1990; Wang et al., 2000; Xu et al., 2004). In addition, its larvae are predators of eggs of the grasshopper Chondracris rosea rosea De Geer (Orthoptera: Acridiidae). As the beetle is now scarce in the field it is important to rear large numbers in the laboratory. Therefore, knowledge of the factors inducing diapause in the final instar larvae is important.

\section{MATERIAL AND METHODS}

\section{Insect materials}

Mylabris phalerata adults were collected from cowpea flowers in the fields on farms of Huazhong Agricultural University at Wuhan $\left(30.5^{\circ} \mathrm{N}, 114.3^{\circ} \mathrm{E}\right)$, Hubei Province, People's Republic of China, in June-July 2003. Adult beetles were brought to the laboratory and reared at $25 \pm 1^{\circ} \mathrm{C}, 70 \pm 5 \%$ r.h. and $16 \mathrm{~L}: 8 \mathrm{D}$ in a wire screen cage $(100 \mathrm{~cm} \times 100 \mathrm{~cm}$ at base and $300 \mathrm{~cm}$ deep). A plastic container $(50 \mathrm{~cm} \times 25 \mathrm{~cm}$ at base and $12 \mathrm{~cm}$ deep) was put at the bottom of the cage, which contained moist soil for oviposition and acted as a source of moisture. Adults were fed on cowpea flowers, cowpea pods and flowers of loofah. Daily checks were made and newly laid egg masses of $M$. phalerata were collected and placed in small plastic containers $(4 \mathrm{~cm}$ wide at base and $10 \mathrm{~cm}$ deep). Upon hatching, larvae were placed individually in the same containers filled with fine inorganic soil and a grasshopper egg-pod.

\section{Temperature response experiment}

To investigate the effect of temperature on diapause occurrence in M. phalerata the larvae were reared at 18, 22, 25, 28, 31 or $34 \pm 1^{\circ} \mathrm{C}$ in soil with a water content of $10 \%$ (w : w). 50 individuals were reared at each temperature. Larval moulting and pupation were checked and recorded.

\section{The joint effects of temperature and soil water content}

The joint effects of temperature and soil water content on diapause occurrence in M. phalerata were determined at 25 and 30 $\pm 1{ }^{\circ} \mathrm{C}$ and a water content of $8 \%, 10 \%$ or $12 \%(\mathrm{w}: \mathrm{w})$. Larval moulting and pupation of 50 individuals were checked and recorded for each treatment.

\section{The joint effects of temperature and photoperiod}

The joint effects of temperature and photoperiod on diapause induction in $M$. phalerata were studied by exposing all the immature stages of M. phalerata to $22,24,25,26$ or $28 \pm 1^{\circ} \mathrm{C}$ at photoperiods of $8 \mathrm{~L}: 16 \mathrm{D}, 12 \mathrm{~L}: 12 \mathrm{D}$ or $16 \mathrm{~L}: 8 \mathrm{D}$. The soil water content was $10 \%(\mathrm{w}: \mathrm{w})$. The diapause intensity was measured as diapause duration. Larval moulting and pupation of 50 individuals were recorded.

\section{Sensitivity of larvae to photoperiod and temperature}

Two experiments investigated the sensitivity of larvae to photoperiod and temperature. The first experiment was on pre- $5^{\text {th }}$ instar larvae. Eggs and larvae were kept at $25^{\circ} \mathrm{C}$ or $30^{\circ} \mathrm{C}$ and photoperiods of $8 \mathrm{~L}: 16 \mathrm{D}, 12 \mathrm{~L}: 12 \mathrm{D}$ or $16 \mathrm{~L}: 8 \mathrm{D}$, respectively.

\footnotetext{
* Corresponding author; e-mail: ioir@mail.hzau.edu.cn
} 


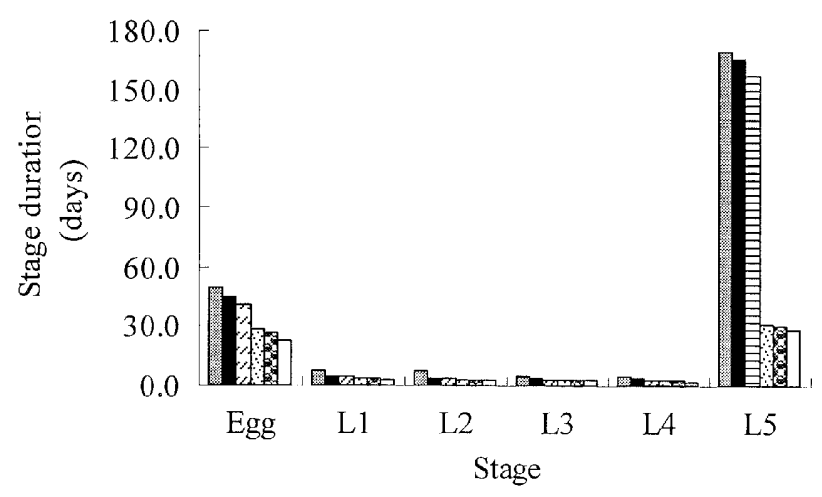

Fig. 1. Duration of development of the immature stages of Mylabris phalerata measured at 18, 22, 25, 28, 31 and $34 \pm$ $1{ }^{\circ} \mathrm{C}$. The soil water content was $10 \%(\mathrm{w}: \mathrm{w})$. The duration of development time is the mean of 50 individuals in each stage.

Larvae kept at $30^{\circ} \mathrm{C}$ were transferred to $25^{\circ} \mathrm{C}$ on the first day of the $1^{\text {st }}, 2 \mathrm{nd}, 3^{\text {rd }}$ or $4^{\text {th }}$ instar but kept at the same photoperiod. Similar larvae kept at $25^{\circ} \mathrm{C}$ were transferred to $30^{\circ} \mathrm{C}$ as above. In the second experiment, the $5^{\text {th }}$ instar larvae were transferred. Individuals reared at $25^{\circ} \mathrm{C}$ were transferred to $30^{\circ} \mathrm{C}$ when they reached $1,30,60,90,120$ or 150 days age. The $5^{\text {th }}$ instar larvae kept at $30^{\circ} \mathrm{C}$ were transferred to $25^{\circ} \mathrm{C}$ when 1,20 or 30 days old. 50 individuals were used in each treatment and the soil water content was $10 \%(\mathrm{w}: \mathrm{w})$. The control group was not transferred. Diapause occurrence and duration were monitored.

\section{The effect of photoperiod and temperature on pupal dura-} tion

Diapausing larvae were kept at 22 or $25^{\circ} \mathrm{C}$ and a photoperiod of $8 \mathrm{~L}: 16 \mathrm{D}, 12 \mathrm{~L}: 12 \mathrm{D}$ or $16 \mathrm{~L}: 8 \mathrm{D}$ and the soil water content was $10 \%(\mathrm{w}: \mathrm{w})$. The non-diapausing larvae were kept at $28^{\circ} \mathrm{C}$. The duration of the pupal stage was recorded in each case.

\section{Diapause identification}

The $5^{\text {th }}$ instar larvae wander before entering the soil. This wandering lasts from the time of the moulting of the $5^{\text {th }}$ instar larvae to when they enter the soil. The wandering of nondiapause individuals lasts for $\leq 2$ days, whereas that of diapause individuals lasts for $\geq 4$ days.

\section{Data analysis}

The difference in the duration of development of each stage in the different treatments was tested for significance by analysis of variance (ANOVA) using SAS (SAS Institute, 1999). The temperature in 2003 and 2004 was monitored by recording daily minimum and maximum temperature. The time required by fifth instar larvae reared under given diapause inducing conditions to reach the pupal stage was used as a measure of diapause intensity.

\section{RESULTS}

\section{Effect of temperature on the rate of development}

Egg development time decreased with increased in temperature from 18 to $34^{\circ} \mathrm{C}$ (Fig. 1). Duration of the first to the fourth instar was longer at $18^{\circ} \mathrm{C}$ than at the other temperatures tested. Larvae kept at temperatures $\geq 22^{\circ} \mathrm{C}$ from the first to the fourth instar took a similar time to complete development. More than $94 \%$ of the fifth instar

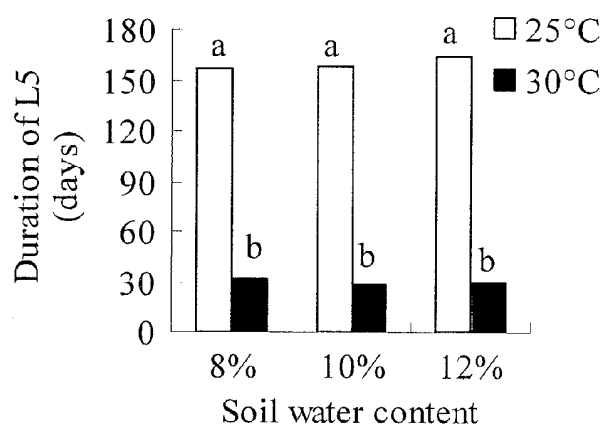

Fig. 2. The average duration of development of $5^{\text {th }}$ instar larvae (L5) of M. phalerata reared at different temperatures and soil water contents. Diapause occurred at $25^{\circ} \mathrm{C}$. Means followed by the same letter are not significantly different $(P>0.05)$.

larvae kept at low temperatures $\left(\leq 25^{\circ} \mathrm{C}\right)$ entered diapause and took five months before they pupated. At 28, 31 and $34^{\circ} \mathrm{C}$ the L5 larvae did not enter diapause and completed development in 28.4-31.5 days.

\section{The effect of soil temperature and water content}

Diapause incidence and duration was not significantly influenced by the water content of the soil. More than $94 \%$ of the larvae kept at $25^{\circ} \mathrm{C}$ entered diapause. At $30^{\circ} \mathrm{C}$ diapause was averted regardless of the soil water content. The duration of diapause at $25^{\circ} \mathrm{C}$ was similar whether the water content of the soil was $8 \%, 10 \%$ or $12 \%$ (Fig. 2).

\section{The effect of temperature and photoperiod}

Most larvae entered diapause at 22,24 and $25^{\circ} \mathrm{C}$, irrespective of the photoperiod. However, $100 \%$ of the larvae developed without diapausing at temperatures $>25^{\circ} \mathrm{C}$ $\left(26^{\circ} \mathrm{C}\right.$ and $\left.28^{\circ} \mathrm{C}\right)$, regardless of the photoperiod (Table 1). The critical temperature for diapause induction was between $25^{\circ} \mathrm{C}$ and $26^{\circ} \mathrm{C}$.

The development of the non-diapausing L5 was five times faster than that of larvae that entered diapause (Table 2). The duration of diapause did not differ significantly at 22,24 and $25^{\circ} \mathrm{C}$; though it was shortest at $25^{\circ} \mathrm{C}$. Photoperiod did not significantly influence the duration of diapause, though at $12 \mathrm{~L}: 12 \mathrm{D}$, diapausing larvae required a slightly shorter time to complete development than at $8 \mathrm{~L}: 16 \mathrm{D}$ and $16 \mathrm{~L}: 8 \mathrm{D}$.

\section{Sensitivity of larvae to photoperiod and temperature}

Rearing eggs and young larvae at different photoperiods did not affect diapause induction. Individuals exposed in the egg stage and L1-L4 to $25^{\circ} \mathrm{C}$ experienced

TABLE 1. Incidence of diapause in $5^{\text {th }}$ instar larvae (L5) of Mylabris phalerata reared at different temperatures and photoperiods in soil with a water content of $10 \%(\mathrm{w}: \mathrm{w})$.

\begin{tabular}{cccc}
\hline \multirow{3}{*}{ Temperature $\left({ }^{\circ} \mathrm{C}\right)$} & \multicolumn{3}{c}{ Photoperiod } \\
\cline { 2 - 4 } & $8 \mathrm{~L}: 16 \mathrm{D}$ & $12 \mathrm{~L}: 12 \mathrm{D}$ & $16 \mathrm{~L}: 8 \mathrm{D}$ \\
\hline 22 & $100 \%$ & $100 \%$ & $100 \%$ \\
24 & $98 \%$ & $96 \%$ & $98 \%$ \\
25 & $94 \%$ & $94 \%$ & $96 \%$ \\
26 & 0 & 0 & 0 \\
28 & 0 & 0 & 0 \\
\hline
\end{tabular}


TABLE 2. The joint effect of photoperiod and temperature, when the soil water content was $10 \%(\mathrm{w}$ : w), on the duration of the fifth larval instar of Mylabris phalerata.

\begin{tabular}{lrrr}
\hline \multirow{2}{*}{$\begin{array}{l}\text { Temperature } \\
{ }^{\circ} \mathrm{C}\end{array}$} & \multicolumn{3}{c}{ Duration of L5 (days) } \\
\cline { 2 - 4 } & \multicolumn{1}{c}{$8 \mathrm{~L}: 16 \mathrm{D}$} & \multicolumn{1}{c}{$12 \mathrm{~L}: 12 \mathrm{D}$} & \multicolumn{1}{c}{$16 \mathrm{~L}: 8 \mathrm{D}$} \\
\hline 22 & $165.4 \pm 5.1 \mathrm{a}$ & $162.5 \pm 3.9 \mathrm{a}$ & $167.2 \pm 4.4 \mathrm{a}$ \\
24 & $161.3 \pm 3.2 \mathrm{a}$ & $158.7 \pm 3.7 \mathrm{a}$ & $163.1 \pm 4.1 \mathrm{a}$ \\
25 & $157.5 \pm 4.0 \mathrm{a}$ & $154.3 \pm 3.5 \mathrm{a}$ & $158.2 \pm 3.3 \mathrm{a}$ \\
$26(\mathrm{ND})$ & $34.5 \pm 3.1 \mathrm{~b}$ & $33.2 \pm 2.9 \mathrm{~b}$ & $32.5 \pm 3.1 \mathrm{~b}$ \\
$28(\mathrm{ND})$ & $30.2 \pm 2.6 \mathrm{~b}$ & $29.1 \pm 2.5 \mathrm{~b}$ & $31.6 \pm 6.7 \mathrm{~b}$ \\
\hline
\end{tabular}

Note: Means in a column with the same letter are not significantly different $(P>0.05, \mathrm{n}=50)$. ND non-diapause larvae.

diapause in L5, but by such exposure to $30^{\circ} \mathrm{C}$ diapause was averted (Table 3). Individuals that were reared at $25^{\circ} \mathrm{C}$ until $\mathrm{L} 1$ or $\mathrm{L} 2$ and then transferred to $30^{\circ} \mathrm{C}$ did not enter diapause. Less intense diapause was induced if $\mathrm{L} 3$ and $\mathrm{L} 4$, or $\mathrm{L} 4$ were reared at $30^{\circ} \mathrm{C}$. In contrast, diapause of normal length occurred in two treatments in which the larvae were transferred from 30 to $25^{\circ} \mathrm{C}$ in the first days of L1 or L2. And diapause was averted when they were transferred from 30 to $25^{\circ} \mathrm{C}$ on day 1 of L3 or L4 (i.e., when egg-L2 or egg-L3 were reared at $30^{\circ} \mathrm{C}$ ). Individuals exposed in egg-L5 to $30^{\circ} \mathrm{C}$ developed without diapause. Individuals exposed in egg-L5 to $25^{\circ} \mathrm{C}$ entered diapause and age of L5 did not affect diapause induction. The early stages, particularly L2 appeared to be more sensitive to diapause induction than the later stages. However, other instars were also sensitive, as shown by the gradual increase in the duration of L5 when transferrs from 25 to $30^{\circ} \mathrm{C}$ occurred at later stage in development (Table 3 ). It seems that the later exposure to $30^{\circ} \mathrm{C}$ reverses the previous diapause induction by $25^{\circ}$; the degree depends on the duration of exposure.

\section{Diapause intensity}

Diapause duration of individuals reared from the egg stage at $25^{\circ} \mathrm{C}$ was $157.5-158.2$ days (Table 3 ). That of individuals exposed to $30^{\circ} \mathrm{C}$ before the third instar and $25^{\circ} \mathrm{C}$ throughout their subsequent development lasted 145.3-151.6 days. However, the diapause duration of individuals transferred from 25 to $30^{\circ} \mathrm{C}$ on the first day of L3 or L4 was shorter than that of individuals reared at $25^{\circ} \mathrm{C}$ throughout their development. The diapause duration was 67.9-68.5 days when transferred on the first day of L3 and 75.0-76.9 days when transferred on the first day of L4. Individuals transferred on either the first or thirtieth day of $\mathrm{L} 5$ from 30 to $25^{\circ} \mathrm{C}$ took about three months to pupate, those transferred on day 60 took about four months and those on day 90 nearly five months. Development to the pupal stage of L5 kept at $30^{\circ} \mathrm{C}$ took one month (Table 3).

TABLE 3. Duration of development of L5 of Mylabris phalerata reared under different photoperiods and transferred at different stages during their development from 30 to $25^{\circ} \mathrm{C}$ or from 25 to $30^{\circ} \mathrm{C}(\mathrm{n}=50)$.

\begin{tabular}{|c|c|c|c|c|}
\hline \multicolumn{2}{|c|}{ Stages exposed to } & \multicolumn{3}{|c|}{ Duration of stage L5 } \\
\hline $25^{\circ} \mathrm{C}$ & $30^{\circ} \mathrm{C}$ & $8 \mathrm{~L}: 16 \mathrm{D}$ & $12 \mathrm{~L}: 12 \mathrm{D}$ & $16 \mathrm{~L}: 8 \mathrm{D}$ \\
\hline Egg-L5 & & 157.5 & 154.3 & 158.2 \\
\hline L1-L5 & Egg & 151.6 & 145.3 & 144.8 \\
\hline L2-L5 & Egg-L1 & 146.3 & 145.8 & 145.7 \\
\hline L3-L5 & Egg-L2 & 36.9 & 35.7 & 38.4 \\
\hline L4-L5 & Egg-L3 & 33.8 & 32.4 & 32.2 \\
\hline L5 & Egg-L4 & 32.1 & 31.2 & 30.8 \\
\hline The other stage of L5 & Egg-L5(10) ${ }^{*}$ & 32.3 & 31.3 & 32.5 \\
\hline \multirow[t]{2}{*}{ The other stage of L5 } & Egg-L5(20) & 30.7 & 30.1 & 30.0 \\
\hline & Egg-L5 & 28.2 & 29.1 & 28.4 \\
\hline Egg & L1-L5 & 32.4 & 33.3 & 33.4 \\
\hline Egg-L1 & L2-L5 & 38.6 & 37.9 & 37.8 \\
\hline Egg-L2 & L3-L5 & 68.2 & 67.9 & 68.5 \\
\hline Egg-L3 & L4-L5 & 76.4 & 76.9 & 75.0 \\
\hline Egg-L4 & L5 & 93.1 & 92.3 & 94.5 \\
\hline Egg-L5(10) & The other stage of L5 & 95.5 & 94.5 & 97.0 \\
\hline Egg-L5(30) & The other stage of L5 & 100.1 & 98.3 & 99.2 \\
\hline Egg-L5(60) & The other stage of L5 & 120.9 & 118.8 & 120.2 \\
\hline Egg-L5(90) & The other stage of L5 & 136.2 & 138.5 & 139.0 \\
\hline Egg-L5(120) & The other stage of L5 & 139.9 & 140.7 & 141.4 \\
\hline Egg-L5(150) & The other days of L5 & 155.5 & 155.8 & 154.9 \\
\hline
\end{tabular}

\footnotetext{
*: number in the bracket is the age in days of L5.
} 
TABLE 4. The effect of photoperiod and temperature, when soil water content was $10 \%(\mathrm{w}: \mathrm{w})$, on the duration of the pupal stage of Mylabris phalerata.

\begin{tabular}{lccc}
\hline \multirow{2}{*}{$\begin{array}{l}\text { Temperature } \\
\left({ }^{\circ} \mathrm{C}\right)\end{array}$} & \multicolumn{3}{c}{ Duration of pupal stage (days) } \\
\cline { 2 - 4 } 22 & $8 \mathrm{~L}: 16 \mathrm{D}$ & $12 \mathrm{~L}: 12 \mathrm{D}$ & $16 \mathrm{~L}: 8 \mathrm{D}$ \\
\hline 25 & $27.3 \pm 2.1 \mathrm{a}$ & $27.4 \pm 2.3 \mathrm{a}$ & $28.8 \pm 2.5 \mathrm{a}$ \\
28 & $20.9 \pm 2.2 \mathrm{~b}$ & $19.8 \pm 3.0 \mathrm{~b}$ & $21.1 \pm 1.9 \mathrm{~b}$ \\
\hline
\end{tabular}

Note: Means with the same letter are not significantly different $(\mathrm{P}>0.05, \mathrm{n}=50)$.

\section{The effect of photoperiod and temperature on the duration of pupal stage}

The duration of the pupal stage decreased with increased temperature (Table 4). The larvae that did not diapause at $28^{\circ} \mathrm{C}$ needed 17 days to complete the pupal stage, which was nearly ten days faster than for the larvae reared at $22^{\circ} \mathrm{C}$ and that were in diapause in L5. Adult beetles normally emerged 20 days after pupation at $25^{\circ} \mathrm{C}$, which was a week faster than at $22^{\circ} \mathrm{C}$. Duration of pupal development at each temperature was not significantly different at photoperiod $8 \mathrm{~L}: 16 \mathrm{D}, 12 \mathrm{~L}: 12 \mathrm{D}$ or $16 \mathrm{~L}: 8 \mathrm{D}$ (Table 4).

\section{DISCUSSIONS}

The present study indicates that diapause in the final instar larvae of $M$. phalerata is induced by temperature rather than the water content of the soil or photoperiod. Diapause induction was averted at temperatures $\geq 26^{\circ} \mathrm{C}$, but induced by temperatures $\leq 25^{\circ} \mathrm{C}$. It can be concluded that high temperatures act as a diapause-averting factor in this insect and the critical temperature for diapause induction is between 25 and $26^{\circ} \mathrm{C}$ as at or below $25^{\circ} \mathrm{C}$ almost all individuals entered diapause. Temperature-controlled diapause is also reported by Shintani \& Ishikawa (1997) in Psacothea hilaris and by Ishihara \& Shimada (1995) in Kytorhinus sharpianus. Xue mentioned that diapause in Colaphellus bowringi is induced principally by low temperature and less so by photoperiod (Xue et al., 2002). The same response is seen in Endopiza viteana (Tobin et al., 2002). Earlier examples are cited in Beck (1991). The role of temperature in these insects is more important for inducing diapause than regulating development rate.

The duration of diapause in $M$. phalerata reared at the same temperature was not affected by the water content of the soil of $8 \%, 10 \%$ or $12 \%$, or photoperiods of $8 \mathrm{~L}$ : $16 \mathrm{D}, 12 \mathrm{~L}: 12 \mathrm{D}$ or $16 \mathrm{~L}: 8 \mathrm{D}$. However, the soil temperature greatly influenced diapause duration (Table 2). Diapause duration at $22^{\circ} \mathrm{C}$ was longer than at 24 and $25^{\circ} \mathrm{C}$. Several authors indicate that lower temperatures can prolong development (Ratte, 1985; Sibly \& Calow, 1986; Atkinson, 1994; Nylin, 1994; Abrams et al., 1996).

The stages sensitive to induction of diapause of the final larval instars are reported, for instance, by Kurota \& Shimada (2001) for Bruchidius dorsalis and Milonas \& Savopoulou-Soultani (2000) for Colpoclypeus florus. B. dorsalis enters diapause in the final (late fourth) larval instar under short photoperiods and the stages sensitive to

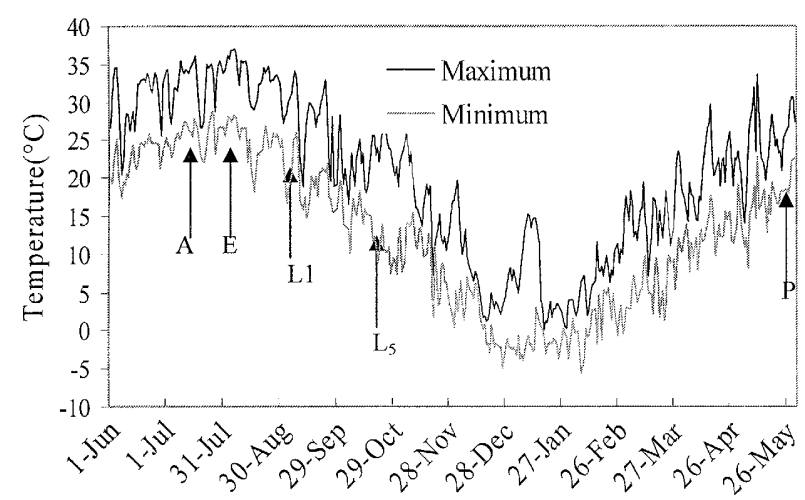

Fig. 3. Life cycle of Mylabris phalerata and the daily maximum and minimum temperatures in 2003-2004. Arrows indicate the date of appearance of the life stages of $M$. phalerata. A: adult, E: egg, L1: the first instar larva, L5: the fifth instar larva (overwintering stage), P: pupa

photoperiod are the late egg stage and early first instar larva. The pupa of the maternal generation is the most sensitive stage for the induction of larval diapause in $C$. florus. In this study, exposure of larvae of $M$. phalerata to low temperature $\left(\leq 25^{\circ} \mathrm{C}\right)$ from $\mathrm{L} 3$ onward results in diapause induction in the final instar (Fig. 3).

In the field the final instar larvae entered diapause at the end of October (Fig. 3). Temperature recordings suggest that the maximum temperature dropped below $25^{\circ} \mathrm{C}$ in October, which induced the beetles to enter diapause at this time. The minimum temperature in winter is $-5^{\circ} \mathrm{C}$. As in other insects, diapause enables $M$. phalerata to survive the low temperature conditions prevailing in winter. Temperature remained $\leq 25^{\circ} \mathrm{C}$ up to the end of May (Fig. 3) and prevented beetles from pupating, which resulted in beetles emerging in early July when cowpea flowers are available in the field.

ACKNOWLEDGEMENTS. The authors thank D.L. Denlinger (Department of Entomology, Ohio State University, USA) for critically reading the manuscript. I. Hodek (Institute of Entomology, Czech Academy of Sciences, Czech Republic) is gratefully acknowledged for providing valuable documents and commenting on the manuscript. The authors also thank two anonymous referees for their comments.

\section{REFERENCES}

Abrams P.A., Leimar O., Nylin S. \& Wiklund C. 1996: The effect of flexible developments on optimal sizes and development times in a seasonal environment. Am. Nat. 147: 381-395.

AtKinson D. 1994: Temperature and organism size - A biological law for ectotherms? Adv. Ecol. Res. 25: 1-58.

BECK S.D. 1991: Thermoperiodism. In Lee R.E. \& Denlinger D.L. (eds): Insects at Low Temperature. Chapman and Hall, New York, pp. 199-228.

DANKs H.V. 1987: Insect Dormancy: An Ecological Perspective. Biological Survey of Canada, Ottawa, $439 \mathrm{pp}$.

Hundt H.K., Steyn J.M. \& Wagner L. 1990: Post-mortem serum concentration of cantharidin in a fatal case of cantharides poisoning. Human Exp. Toxicol. 9: 35-40.

IsHiHARA M. \& ShIMAdA M. 1995: Photoperiodic induction of larval diapause and temperature-dependent termination in a 
wild multivoltine bruchid, Kytorhinus sharpianus. Entomol. Exp. Appl. 75: 127-135.

Kurota H. \& Shimada M. 2001: Photoperiod- and temperaturedependent induction of larval diapause in a multivoltine bruchid, Bruchidius dorsalis. Entomol. Exp. Appl. 99: 361-369.

Lee R.E. \& Denlinger D.L. 1990: Insects at Low Temperature. Chapman and Hall, New York and London, 513 pp.

Milonas P.G. \& Savopoulou-Soultani M. 2000: Diapause induction and termination in the parasitoid Colpoclypeus florus (Hymenoptera: Eulophidae): Role of photoperiod and temperature. Ann. Entomol. Soc. Am. 93: 512-518.

NYLIN S. 1994: Seasonal plasticity and life-cycle adaptations in butterflies. In Danks H.V. (ed.): Insect Life-Cycle Polymorphisms. Kluwer, Dordrecht, 396 pp.

RAtTE H.T. 1985: Temperature and insect development. In Hoffman K.H. (ed.): Environmental Physiology and Biochemistry of Insects. Springer, Berlin-Heidelberg, pp. 33-66.

SAUNDERS D.S. 2002: Insect Clocks. 3rd ed. Elsevier Science, Amsterdam, 576 pp.

Shintani Y. \& IshiKawa Y. 1997: Diapause avoidance induced by low temperature in the yellow-spotted longicorn beetle, Psacothea hilaris. Entomol. Exp. Appl. 85: 11-15.
Sibly R.M. \& Calow P. 1986: Physiological Ecology of Animals. Blackwell Science, Oxford, 179 pp.

Tauber M.J., TAuber C.A. \& Masaki S. 1986: Seasonal Adaptations of Insects. Oxford University Press, New York, 411 pp.

Tobin P.C., Nagarkatti S. \& SAUNDERS M.C. 2002: Diapause maintenance and termination in grape berry moth (Lepidoptera: Tortricidae). Environ. Entomol. 31: 708-713.

WANG C.C., Wu C.H., Hsien K.J., Yen K.Y., \& YANG L.L. 2000: Cytotoxic effects of cantharidin on the growth of normal and carcinoma cells. Toxicology 147: 77-87.

WANG G.S. 1989: Medical uses of Mylabris in ancient China and recent studies. J. Ethnopharm. 26: 147-162.

Xu M.Z., Lee W.S., Kim Mi J., Park D.S., Yu H., Tian G.R., JEONG T.S. \& PARK H.Y. 2004: Acyl-CoA: cholesterol acyltransferase inhibitory activities of fatty acid amides isolated from Mylabris phalerata Pallas. Bioorg. Med. Chem. Letters 14: 4277-4280.

Xue F.S., Spieth H.R., Li A.Q. \& Hua A. 2002: The role of photoperiod and temperature in determination of summer and winter diapause in the cabbage beetle, Colaphellus bowringi (Coleoptera: Chrysomelidae). J. Insect Physiol. 48: 279-286.

Received July 21, 2005; revised and accepted March 1, 2006 